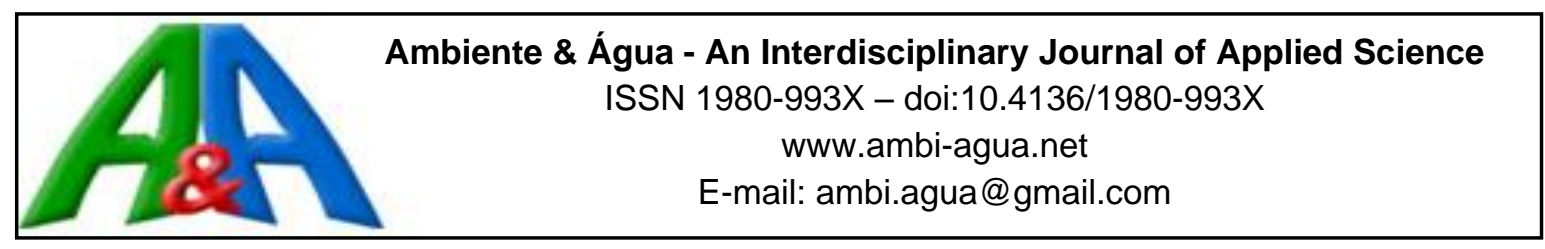

\title{
Contribution of public squares to the reduction of urban flooding risk
}

ARTICLES doi:10.4136/ambi-agua.2374

Received: 07 Feb. 2019; Accepted: 23 Sep. 2019

\author{
Nílberte Muniz de Sousa ${ }^{\text {* (DD }}$; Willames de Albuquerque Soares ${ }^{1}$; \\ Simone Rosa da Silva ${ }^{1}$; ; Elivelthon Carlos do Nascimento ${ }^{1}$ (iD) \\ ${ }^{\mathbf{1}}$ Escola Politécnica de Pernambuco. Departamento de Engenharia Civil. Universidade de Pernambuco (UPE), \\ Rua Benfica, n 455, CEP 50720-001, Recife, PE, Brazil. E-mail: was@ poli.br, \\ simonerosa@poli.br, elivelthonnascimento@gmail.com \\ *Corresponding author. E-mail: nilberte.muniz@hotmail.com
}

\begin{abstract}
Urbanization is directly linked to the process of impermeabilization of the soil in urban areas that contributes to the emergence of flood risks. The purpose of this study was to determine the hydrodynamic properties of the public squares in a flood-prone Brazilian city and determine to what extent they could contribute to the reduction of flooding. The Beerkan method was used to determine the hydrodynamic properties of the soil in nine squares located at critical flooding points in the city of Recife. This method uses simple ring infiltration and the collection of soil samples to obtain the soil granulometric distribution, thereby generating the soil water retention curve $\theta(\mathrm{h})$ and the hydraulic conductivity $K(\theta)$. The squares studied have similar hydrodynamic characteristics because of their similar soil texture classes, such as Loamy Sand and Sandy Loam. This made it possible for eight of the nine squares studied to be able to contribute positively to the reduction of flood risks by adapting them into micro infiltration basins that can receive the surface flows that overload the drainage network.
\end{abstract}

Keywords: beerkan, hydrodynamic properties, infiltration basins.

\section{A contribuição das praças públicas na redução dos riscos de alagamentos urbanos}

\section{RESUMO}

A urbanização está diretamente ligada ao processo de impermeabilização do solo em áreas urbanas que acaba contribuindo no surgimento dos riscos de alagamentos. Desse modo, objetivou-se nessa pesquisa determinar as propriedades hidrodinâmicas das praças púbicas de uma cidade Brasileira e com isso determinar o quanto podem contribuir para a redução de alagamentos. Para tanto foram utilizado o método Beerkan para determinar as propriedades hidrodinâmicas do solo em nove praças localizadas em pontos críticos de alagamentos na cidade do Recife. O método utiliza ensaios de infiltração de anel simples e coletas de amostras de solos para obter a distribuição granulométrica do solo, com isso, gerar a curva de retenção da água no solo $\theta(\mathrm{h})$ e a condutividade hidráulica $\mathrm{K}(\theta)$ através dos modelos de Van Genuchten (1980) e de Brooks e Corey. As praças estudadas apresentam características parecidas, uma vez que possuem classes texturais próximas sendo elas Areia Franca e Franco Arenosos. O que fez com que das nove praças estudadas, oito apresentassem aptidão para contribuir de maneira positiva na redução dos riscos de alagamentos, através da sua adaptação em microbacias de infiltração para que posam receber os escoamentos superficiais que sobrecarregam as estruturas de drenagem. 
Palavras-chave: bacias de infiltração, beerkan, propriedades hidrodinâmicas.

\section{INTRODUCTION}

The process of urbanization makes it necessary for cities to develop as their population grows. This process consists of the construction of houses and infrastructure, which leads to a reduction in the natural infiltration capacity of the soil through the transformation of permeable surfaces that reduce the flow of water into impermeable surfaces that must be served by a rainwater drainage system.

Rainwater runoff caused by impermeable surfaces associated with urbanization has become a major source of water pollution and can cause street flooding and watershed degradation (Meng and Hsu, 2019).

Traditional construction techniques and increased urbanization contribute to reduced soil absorption capacity and rainwater storage through waterproofing, which results in an increased risk of flooding, pollution transport and overloaded stormwater piping systems (Berndtsson et al., 2019).

Because of this, there is an urgent need for better rainwater management practices. In urban areas in France, for example, dry infiltration basins are used to reduce the volume of water in downstream networks and limit the discharge of pollution into surface water. These basins can also promote urban development in areas far from existing networks or in natural outlets and improve urban locations where basins can be used as parks or playgrounds. Lower costs and recharging of groundwater are other potentially attractive aspects of appropriate management practices (Dechesne et al., 2004).

Infiltration basins are stormwater control measures that capture, temporarily store and gradually infiltrate secondary runoff into the ground, thereby reducing the net runoff volume (Natarajan and Davis, 2016).

To implement this practice, it is necessary to determine the hydrodynamic behavior of the water in the soil. For this purpose, many authors such as Oliveira et al. (2018); Santos et al. (2012), Bagarello et al. (2014), Lassabatère et al. (2010), and Souza et al. (2008) make use of the Beerkan method proposed by Lassabatère et al. (2006). Knowledge of these hydrodynamic soil parameters is directly linked to understanding the process of water infiltration into the soil.

Oliveira and Soares (2017) determined the saturated hydraulic conductivity at nine distinct points in an area susceptible to flooding in the city of Recife using the Beerkan method. The results obtained from the infiltration curves can be used in a variety of modeling or forecast studies, for periods of long or short duration, that estimate the water balance in the locality (rain $x$ infiltration), the cumulative water capacity in the soil, and the performance with regard to urban drainage.

The objective of this study was to estimate potential infiltration in public squares near flood-prone areas in a flood-prone Brazilian city, and to determine how much these squares can contribute to the infiltration of rainwater into the soil, thereby reducing the risk of flooding.

\section{MATERIALS AND METHODS}

The research was carried out in the city of Recife, Pernambuco, which has a total area of $218,435 \mathrm{~km}^{2}$ and had an estimated population of 1,633,697 inhabitants in 2017. The city has a total of 413 public squares, and 159 critical flooding points catalogued by EMLURB (Urban Maintenance and Sanitation Company). The locations of the squares and critical flooding points are shown in Figure 1. 


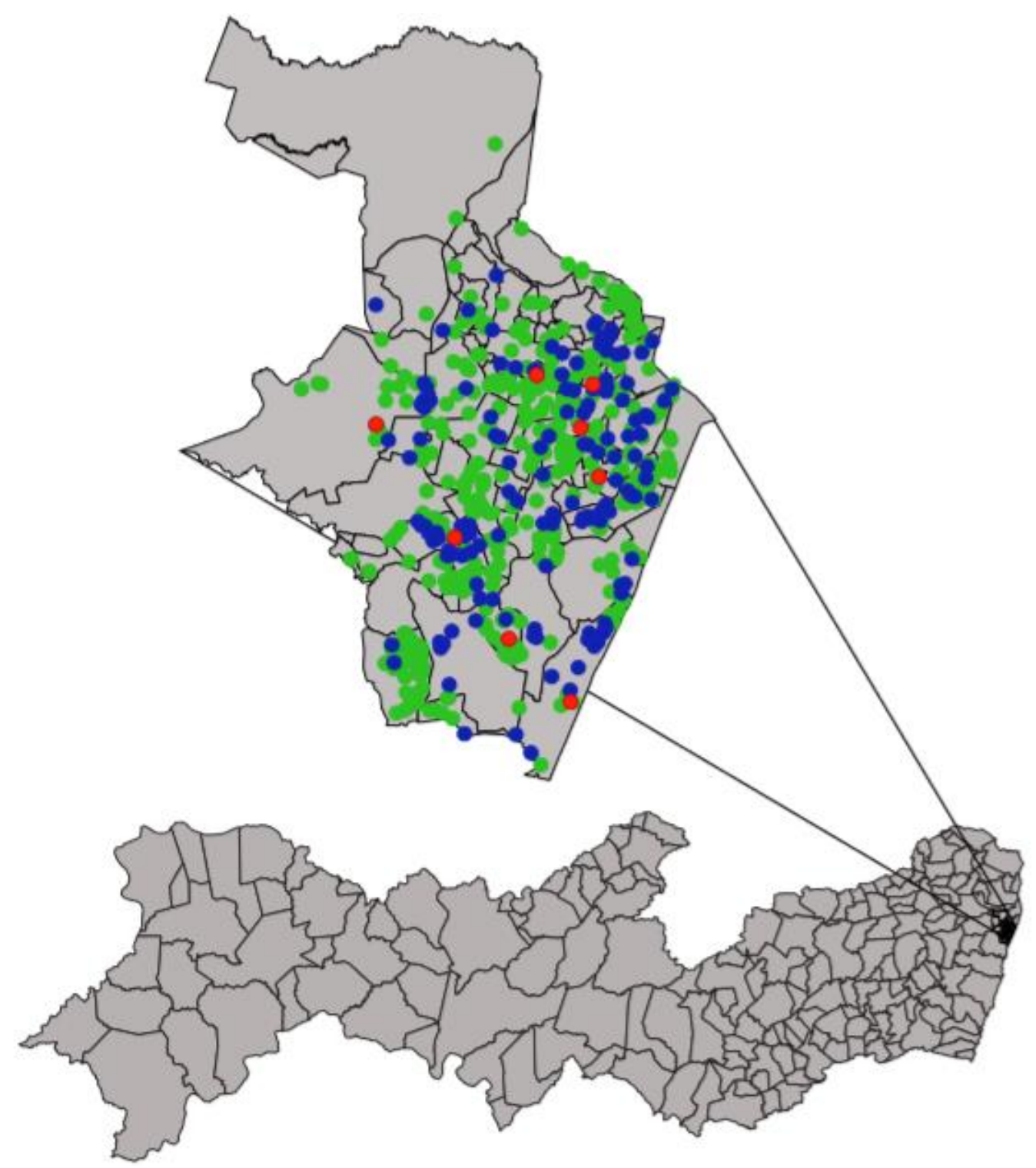

\section{Legend}

- Public Squares

- Public squares studied

- Critical points of flooding

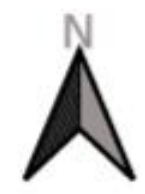

Figure 1. Public squares and critical flooding points in the city of Recife-PE.

This study focused on eight of the total number of squares, all of which were located near critical flooding points and were not waterproofed. They are Dom Miguel Valverde Square, with an area of $2075 \mathrm{~m}^{2}$ and a permeable soil rate of $74.40 \%$; Dr. José Vilela Square, with a total area of $2206 \mathrm{~m}^{2}$ and a permeable soil rate of 56.98\%; Dr. Fernando Figueira Square, with $4921 \mathrm{~m}^{2}$ total area and a permeable soil rate of $59.09 \%$; Entroncamento Square, with a permeable soil rate of $38.80 \%$ and a total area of $5125 \mathrm{~m}^{2}$; Nossa Senhora da Boa Viagem Square, with an area of $8101 \mathrm{~m}^{2}$ and a permeable soil rate of only $12.39 \%$; Jardim São Paulo Square, which has an area of $5675 \mathrm{~m}^{2}$ and a permeable soil rate is $68.22 \%$; SUDENE Square, with an area of $4316 \mathrm{~m}^{2}$ and $67.81 \%$ of permeable soil; and Várzea Square with $5809 \mathrm{~m}^{2}$ total area and $27.80 \%$ permeable soil (Figure 2). 


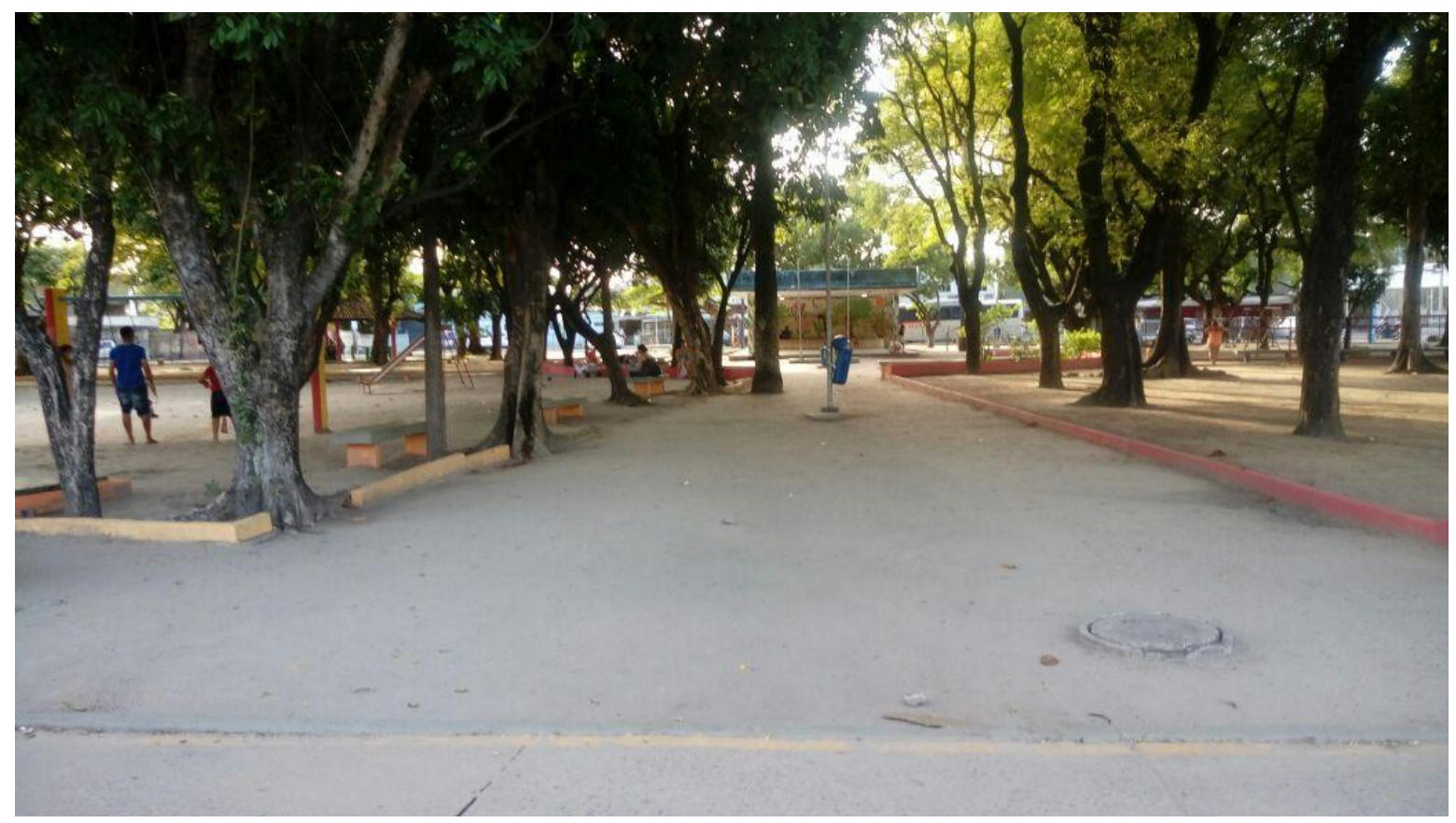

Figure 2. Jardim São Paulo Square.

In the surveyed squares, it was observed that only three of them presented non-sealed soil area less than $50 \%$ of their total area.

\subsection{Field Studies and Sample Collection}

At each of the public squares studied, simple ring infiltration assays and sample collections were performed nine times to determine the particle-size distribution curves.

The simple ring infiltration test is performed by inserting a $15 \mathrm{~cm}$ diameter metal cylinder into the ground to a depth of approximately 1 centimeter and then pouring a known volume of water into the cylinder that is sufficient enough to form a layer of water on the surface of the soil inside the infiltrator. When the sheet of water has dried and the soil inside the infiltrator has become exposed, the same volume of water is poured again. During the test, the time elapsed between the additions of water was measured and the process was repeated until the relationship between the volume of water infiltrated and the time became constant.

The samples collected to determine the particle-size distribution curves were taken to a laboratory, where the sample preparation procedures were carried out. The particle-size distribution was obtained using the screening and sedimentation processes defined in NBR 7181 (ABNT, 2016).

\subsection{Beerkan Method}

The Beerkan methodology is performed through infiltration and particle-size distribution tests, and is used to determine local hydrodynamic parameters in the field. In this method, the soil water-retention curve $\theta(\mathrm{h})$ and the hydraulic conductivity $K(\theta)$ are described, respectively, by the model defined by Van Genuchten (1980), represented in Equation 1, and the model defined by Brooks and Corey (1964), shown in Equation 2.

$$
\begin{aligned}
& \theta(h)=\frac{\left(\theta-\theta_{r}\right)}{\left(\theta_{s}-\theta_{r}\right)}=\left[1+\left(\frac{h}{h_{g}}\right)^{n}\right]^{-m} \\
& K(\theta)=K_{s} \cdot\left(\frac{\left(\theta-\theta_{r}\right)}{\left(\theta_{s}-\theta_{r}\right)}\right)^{\eta}
\end{aligned}
$$


Where $\theta$ is the volumetric moisture $\left[\mathrm{cm}^{3} . \mathrm{cm}^{-3}\right], \theta_{r}$ and $\theta_{s}$ are the residual and saturated volumetric masses $\left[\mathrm{cm}^{3} . \mathrm{cm}^{-3}\right]$, respectively; $h$ is matrix potential $[\mathrm{mm}] ; h_{g}$ is a scale value of $h$; $m$ and $n$ are shape parameters; $K_{s}$ is the saturated hydraulic conductivity of the soil $\left[\mathrm{mm} . \mathrm{s}^{-1}\right.$;; and $\eta$ is the shape parameter for the hydraulic conductivity curve.

Other equations necessary for the use of the BEST method are presented in the studies by Souza et al. (2008) and Santos et al. (2012).

\section{RESULTS AND DISCUSSION}

Graphs were generated from the soil particle-size data determined from the collected samples. The average curves for each public square studied are shown in Figure 3. It is important to note that there were no great variations between them.

Along with the particle-size distribution, the corresponding fractions of clay, silt, and sand were determined for each soil sample, and this was used to indicate the soil textural classes at the studied locations (Table 1).

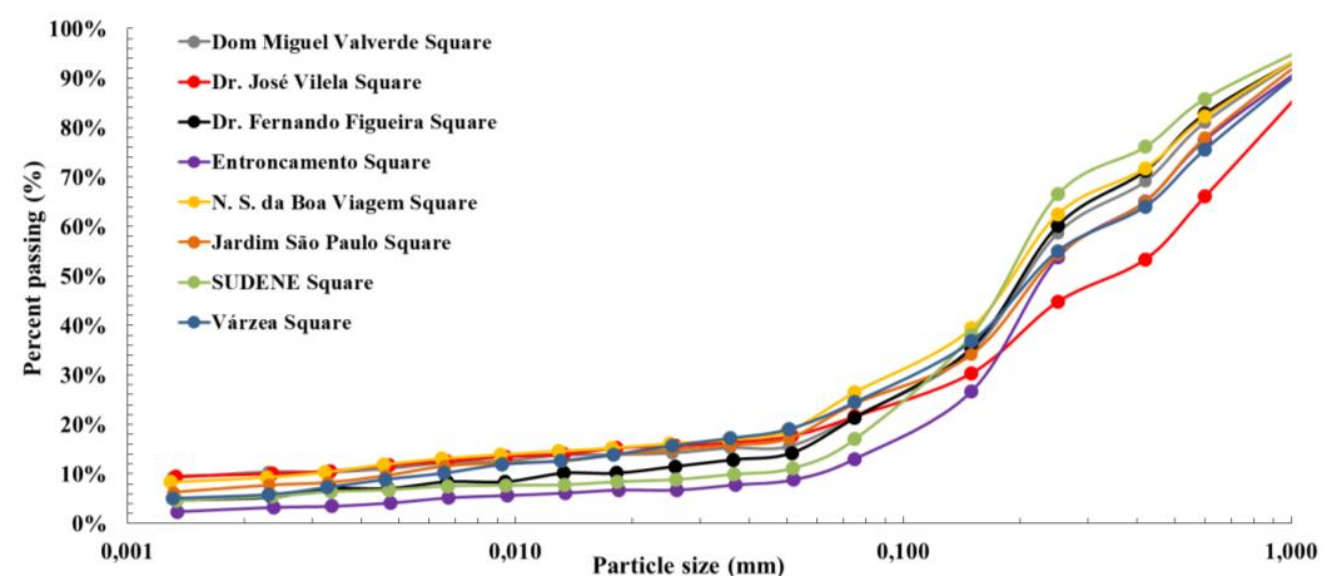

Figure 3. Average particle-size distribution curves.

It can be seen that Jardim São Paulo Square varied the greatest when compared to the other squares, especially with regard to the fraction of medium- and coarse sand corresponding to the region of the graph with particle diameter between $0.200 \mathrm{~mm}$ and $1.000 \mathrm{~mm}$.

In Table 1, the average shape parameters of the retention curve and hydraulic conductivity curve are shown, along with the soil textural classes.

Table 1. Average shape parameters and normalization parameters.

\begin{tabular}{lccccccc}
\hline Square & $\begin{array}{c}\text { Textural } \\
\text { Class }\end{array}$ & $\begin{array}{c}\mathbf{\rho d} \\
\left(\mathbf{g} / \mathbf{c m}^{\mathbf{3}}\right)\end{array}$ & $\mathbf{m}$ & $\mathbf{n}$ & $\boldsymbol{\eta}$ & $\begin{array}{c}\mathbf{K s} \\
\left(\mathbf{m m ~ s} \mathbf{~}^{-1}\right)\end{array}$ & $\begin{array}{c}\mathbf{h g} \\
(\mathbf{m m})\end{array}$ \\
\hline Dom Miguel Valverde Square & Loamy Sand & 1.520 & 0.141 & 2.335 & 9.828 & 0.014 & -0.399 \\
Dr. José Vilela Square & Sandy Loam & 1.654 & 0.126 & 2.289 & 9.963 & 0.030 & -0.734 \\
Dr. Fernando Figueira Square & Loamy Sand & 1.546 & 0.149 & 2.356 & 9.118 & 0.016 & -0.441 \\
Entroncamento Square & Loamy Sand & 1.670 & 0.203 & 2.521 & 7.287 & 0.025 & -1.173 \\
N. S. da Boa Viagem Square & Sandy Loam & 1.534 & 0.125 & 2.286 & 9.999 & 0.029 & -0.350 \\
Jardim São Paulo Square & Sandy Loam & 1.653 & 0.133 & 2.306 & 9.551 & 0.017 & -0.654 \\
SUDENE Square & Loamy Sand & 1.486 & 0.153 & 2.362 & 8.656 & 0.084 & -0.350 \\
Várzea Square & Sandy Loam & 1.525 & 0.125 & 2.286 & 10.187 & 0.001 & -0.111 \\
\hline \hline
\end{tabular}


Note that for the Loamy Sand textural class, Dom Miguel Valverde Square presented the lowest values calculated for parameters $m$ and $n$, while for the Sandy Loame class, the lowest values calculated for parameters $m$ and $n$ were obtained at Nossa Senhora da Boa Viagem Square and Várzea Square.

It can be emphasized that calculated parameters $(m, n$, and $\eta$ ) agree satisfactorily among the soils with the same textural classes in studies carried out by Souza et al. (2008) and Santos et al. (2012).

It is possible to perceive the coherence between the parameters obtained by Souza et al. (2008) and the values determined in Table 1 . The values for parameters $m, n$, and $\eta$ were 0.13 , 2.31 , and 9.54, respectively for soils of the loamy sand texture, while sandy loam soils presented the following values: 0.07, 2.16, and 15.67.

The saturated hydraulic conductivity, $K_{s}$, is affected by the texture of the soil, but depends mainly on its structure. Soils having a larger average particle diameter tend to be better conductors of water.

Souza et al. (2008) estimated and analyzed the soil hydraulic properties through infiltration experiments applying BEST, discovering an average $K_{s}$ value of $0.03 \mathrm{~mm} . \mathrm{s}^{-1}$ for soils in the loamy sand textural class. For soils having a textural class of sandy loam, they obtained average $K_{s}$ values of $0.13 \mathrm{~mm} \cdot \mathrm{s}^{-1}$ and $0.02 \mathrm{~mm} \cdot \mathrm{s}^{-1}$. Santos et al (2012) also identified mean $K_{s}$ values of $0.144 \mathrm{~mm} . \mathrm{s}^{-1}$ and $0.073 \mathrm{~mm} . \mathrm{s}^{-1}$ for soils in the loamy sand textural class and mean $K_{s}$ values of $0.060 \mathrm{~mm} . \mathrm{s}^{-1}$ and $0.224 \mathrm{~mm} . \mathrm{s}^{-1}$ for soils in the sandy loam textural class. The $K_{s}$ values presented in Table 1 are therefore in accord with the results obtained in previous studies.

\subsection{Retention curves and hydraulic conductivity of soil}

The hydraulic conductivity (Figure 4A) and the retention curves (Figure 4B) were elaborated for each of the squares studied, following the determination of the shape parameters and normalization parameters.

Due to the similarity between the soil textural classes, it can be seen that the conductivity curves present similar aspects. Várzea Square was found to have the lowest hydraulic conductivity while Entroncamento Square had the highest hydraulic conductivity, very similar to that found for the remaining squares.

In the retention curves, it is possible to observe that the soils vary only slightly in moisture content and have a small retention capacity. Even so, it is possible to perceive that the sandy loam soils have slightly higher retention than the loamy sand soils. The squares having soil of textural class loamy sand presented a mean difference in humidity of $0.16 \mathrm{~cm}^{3} \mathrm{~cm}^{-3}$ between $\mathrm{h}$ $=1 \mathrm{~mm}$ and $\mathrm{h}=10 \mathrm{~mm}$, while the squares with soil of textural class sandy loam presented a mean difference in humidity of $0.13 \mathrm{~cm}^{3} \mathrm{~cm}^{-3}$ between $\mathrm{h}=1 \mathrm{~mm}$ and $\mathrm{h}=10 \mathrm{~mm}$.

These results were also observed by Santos et al (2012), who noted that the greater proximity of the particles in the sandy loam soils causes absorption and capillarity to be more intense and that these soils consequently retain more water than loamy sand soils. 

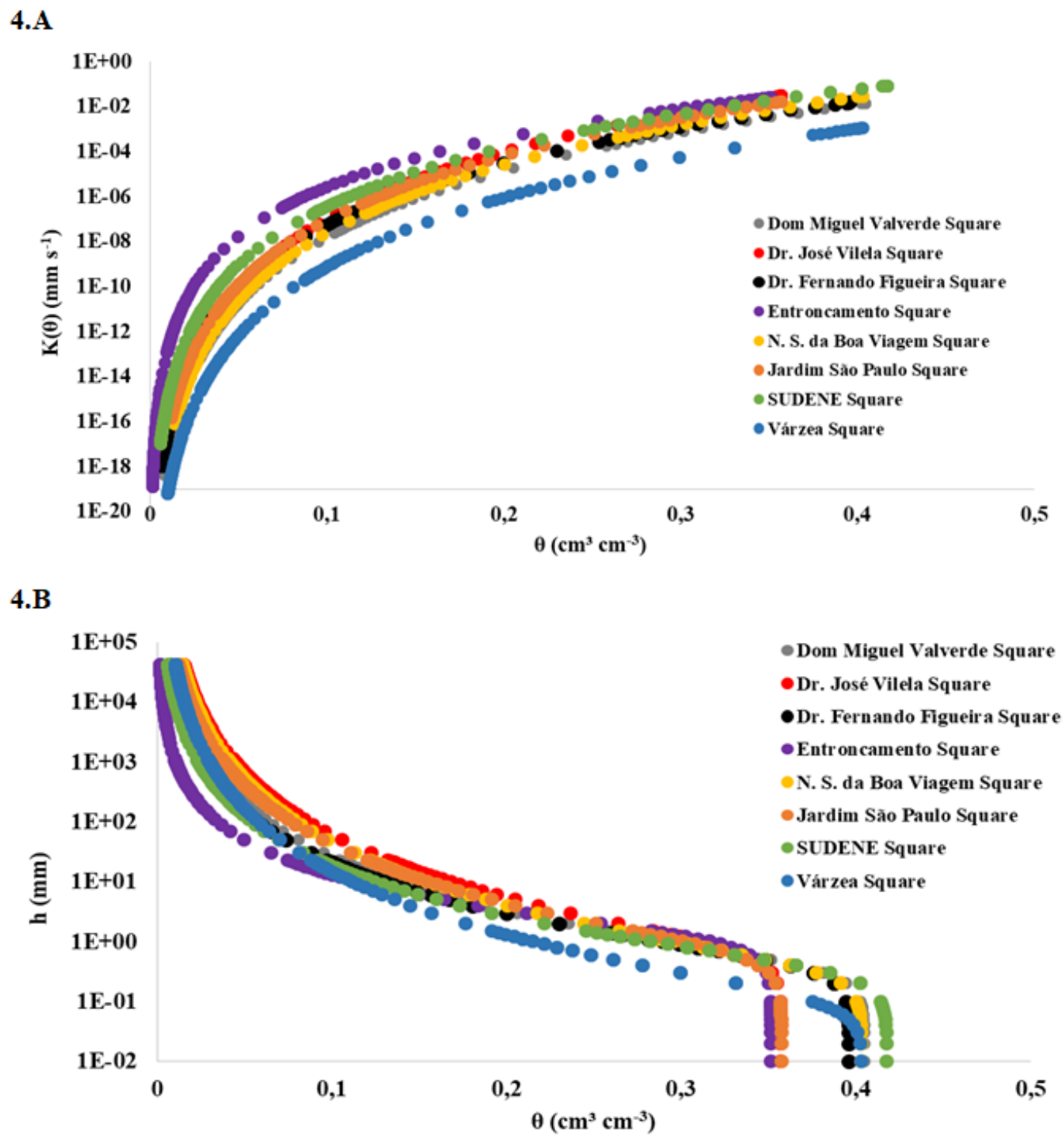

Figure 4. Hydraulic conductivity curves (4A) and Retention curves (4B).

\subsection{Discussion}

From the results obtained, it was possible to determine the infiltration capacity of each of the squares studied and, with that, determine the amount of rain water that each absorbs. The maximum rainfall intensity for Recife, PE determined by Silva Junior and Silva (2016), for a return time of two years and duration of 60 minutes, is $47.44 \mathrm{~mm} \mathrm{~h}^{-1}$, a value then used for each of the squares to establish the volume of surface runoff from the impermeabilized areas the square could receive and absorb, in order to reduce overloading of the drainage system.

Dom Miguel Valverde Square had an infiltration capacity of $50.9 \mathrm{~mm} \mathrm{~h}^{-1}$. Taking into account its total area of permeable soil, it has the capacity to absorb $78.616 \mathrm{~m}^{3}$ of rainwater. During a rainfall event of intensity $47.44 \mathrm{~mm} \mathrm{~h}^{-1}$, it is possible for $73.247 \mathrm{~m}^{3}$ of rainwater to infiltrate. The square could therefore still receive $5.369 \mathrm{~m}^{3}$ of surface flow from its surroundings.

Dr. José Vilela Square has an infiltration capacity of $108.8 \mathrm{~mm} \mathrm{~h}^{-1}$, which allows it to absorb a total of $136.818 \mathrm{~m}^{3}$ of rainfall. During precipitation with an intensity of $47.44 \mathrm{~mm} \mathrm{~h}^{-1}, 59.632 \mathrm{~m}^{3}$ of rainwater can infiltrate. This square could therefore still receive $77.186 \mathrm{~m}^{3}$ of surface runoff from nearby impermeable areas (Table 2). 
Table 2. Mean shape parameters and normalization parameters.

\begin{tabular}{|c|c|c|c|c|c|c|}
\hline Square & $\begin{array}{l}\text { Infiltration rate } \\
\qquad \mathrm{mm} \mathrm{h}^{-1}\end{array}$ & $\begin{array}{c}\text { Ground area not } \\
\text { waterproofed } \\
\text { m }^{2}\end{array}$ & $\begin{array}{c}\text { Absorption } \\
\text { capacity } \\
\text { m}^{2}\end{array}$ & $\begin{array}{l}\text { Max. rainfall Int.* } \\
\mathbf{m m ~ h}^{-1}\end{array}$ & $\begin{array}{c}\text { Infiltration } \\
\mathbf{m}^{3}\end{array}$ & $\begin{array}{l}\text { Able to infiltrate } \\
\qquad \mathbf{m}^{3}\end{array}$ \\
\hline Dom Miguel Valverde Square & 50.9 & 1544 & 78.616 & 47.44 & 73.247 & 5.369 \\
\hline Dr. José Vilela Square & 108.8 & 1257 & 136.818 & 47.44 & 59.632 & 77.186 \\
\hline Dr. Fernando Figueira Square & 56.3 & 2906 & 163.896 & 47.44 & 137.860 & 26.035 \\
\hline Entroncamento Square & 90.3 & 1989 & 179.793 & 47.44 & 94.358 & 85.435 \\
\hline N. S. da Boa Viagem Square & 104.1 & 1004 & 104.595 & 47.44 & 47.629 & 56.966 \\
\hline Jardim São Paulo Square & 60.0 & 3872 & 232.564 & 47.44 & 183.687 & 48.877 \\
\hline SUDENE Square & 302.8 & 2927 & 886.562 & 47.44 & 138.856 & 747.705 \\
\hline Várzea Square & 3.9 & 1615 & 6.4527 & 47.44 & 6.4527 & 0 \\
\hline
\end{tabular}

*Maximum rainfall intensity. 
The infiltration capacity of Dr. Fernando Figueira Square is $56.3 \mathrm{~mm} \mathrm{~h}^{-1}$, allowing it to infiltrate up to $163.896 \mathrm{~m}^{3}$ of rainwater. A rainfall intensity of $47.44 \mathrm{~mm} \mathrm{~h}^{-1}$ would produce a total infiltration of around $137.860 \mathrm{~m}^{3}$ of rainwater in the square, making it is possible to infiltrate another $26.035 \mathrm{~m}^{3}$ of surface runoff.

Entroncamento Square has the capacity to infiltrate $90.3 \mathrm{~mm} \mathrm{~h}^{-1}$, or a total of $179.793 \mathrm{~m}^{3}$ of rainwater. In a rainfall event of intensity $47.44 \mathrm{~mm} \mathrm{~h}^{-1}, 94.358 \mathrm{~m}^{3}$ of rainwater is infiltrated into the soil, allowing for the square to receive $85.435 \mathrm{~m}^{3}$ of water from its surroundings.

Nossa Senhora da Boa Viagem Square has the capacity to infiltrate at a rate of $104.1 \mathrm{~mm}$ $\mathrm{h}^{-1}$, allowing for a total of $104.595 \mathrm{~m}^{3}$ of infiltrated rainwater. With a rainfall intensity of 47.44 $\mathrm{mm} \mathrm{h}^{-1}, 47.629 \mathrm{~m}^{3}$ of rainwater will infiltrate into the soil, allowing the square to potentially receive $56.966 \mathrm{~m}^{3}$ of surface runoff from its surroundings.

Jardim São Paulo Square has an infiltration capacity of $60.0 \mathrm{~mm} \mathrm{~h}^{-1}$, allowing for a total of $232.564 \mathrm{~m}^{3}$ of infiltrated rainwater. Thus, during rainfall of intensity $47.44 \mathrm{~mm} \mathrm{~h}^{-1}, 183.687$ $\mathrm{m}^{3}$ of rainwater will infiltrate into the square, allowing for the infiltration of another $48.877 \mathrm{~m}^{3}$ of surface runoff.

SUDENE Square has an infiltration capacity of $302.8 \mathrm{~mm} \mathrm{~h}^{-1}$, allowing for a total of $886.562 \mathrm{~m}^{3}$ of infiltrated rainwater. In a rainfall event of $47.44 \mathrm{~mm} \mathrm{~h}^{-1}, 138.856 \mathrm{~m}^{3}$ of rainwater will be infiltrated, meaning that the square could still receive a total of $747.705 \mathrm{~m}^{3}$ of surface runoff from the surrounding impermeable areas.

Várzea Square has an infiltration capacity of only $3.9 \mathrm{~mm} \mathrm{~h}^{-1}$, allowing for a total of only $6.452 \mathrm{~m}^{3}$ of infiltrated rainwater. In a rainfall with an intensity of $47.44 \mathrm{~mm} \mathrm{~h}^{-1}$, the square will infiltrate its maximum capacity of $6.452 \mathrm{~m}^{3}$ of rainwater, generating a surface runoff of 70.162 $\mathrm{m}^{3}$, making it impossible to receive any surface runoff from its surroundings that would contribute to flood reduction.

\section{CONCLUSIONS}

The determination of the infiltration capacity at each of the squares studied made it possible to observe that all of them, with the exception of Várzea Square, have the capacity to absorb a quantity of rainwater superior to that which falls directly on the squares themselves.

In squares that have little area free of construction, soils exhibit characteristics such that, were the area of non-sealed soil, it would contribute to infiltration.

Although it does not have the capacity to infiltrate rainwater from surface runoff, the structure of Várzea Square may be modified to enable its contribution. For example, squares may be left lower than roads so that rainwater can be temporarily stored in this area and thus reduce the overhead on the existing drainage system.

The squares could be adapted into micro-infiltration basins, or into retention basins as in the case of Varzea Square, which would contribute directly to the reduction of the existing drainage system by the reduction of runoff.

It is clear that public squares have a great capacity to contribute favorably to the reduction of flooding in large urban centers, which are constantly subject to damage and losses resulting from floods.

\section{REFERENCES}

ASSOCIACAO BRASILEIRA DE NORMAS TECNICAS. NBR 7181: Solo - Análise granulométrica. Rio de Janeiro, 2016.

BAGARELlO, V.; DI PRIMA, S.; GIORDANO, G.; IOVINO, M. A test of the Beerkan Estimation of Soil Transfer parameters (BEST) procedure. Geoderma, v. 221-222, p. 20 27, 2014. https://doi.org/10.1016/j.geoderma.2014.01.017 
BERNDTSSON, R.; BECKER, P.; PERSSON, A.; ASPEGREN, H.; AGHIGHATAFSHAR, S.; JÖNSSON, K.; LARSSON R.; MOBINI, S.; MOTTAGHI, M.; NILSSON, J.; NORDSTRÖM, J.; PILESJÖ, P.; SCHOLZ, M.; STERNUDD, C.; SÖRENSEN, J.; TUSSUPOVA, K. Drivers of changing urban flood risk: A framework for action. Journal $\begin{array}{lllllll}\text { of Environmental Management, } & \text { v. 240, p. 47-56, } 2019 .\end{array}$ https://doi.org/10.1016/j.jenvman.2019.03.094

BROOKS, R. H.; COREY, A. T. Hydraulic properties of porous media. Fort Collins: Colorado State University, 1964.

DECHESNE, M.; BARRAUD, S.; BARDIN, J. P. Indicators for hydraulic and pollution retention assessment of stormwater infiltration basins. Journal of Environmental Management, v. 71, p. 371-380, 2004. https://doi.org/10.1016/j.jenvman.2004.04.005

LASSABATERE, L.; ANGULO-JARAMILLO, R.; GOUTALAND, D.; LETELLIE, L.; GAUDET, J. P.; WINIARSKI, T.; DELOLME, C. Effect of the settlement of sediments on water infiltration in two urban infiltration basins. Geoderma, v. 156, p. 316-325, 2010. https://doi.org/10.1016/j.geoderma.2010.02.031

LASSABATÈRE，L.; ÂNGULO-JARAMILLO，R.; UGALDE，J.M.S.; CUENCA，R.; BRAUD, I.; HAVERKAMP, R. Beerkan Estimation of Soil Transfer Parameters through Infiltration Experiments - BEST. Soil Science Society of America Journal, v. 70, p. 521-532, 2006. https://dx.doi.org/10.2136/sssaj2005.0026

MENG, T.; HSU, D. Stated preferences for smart green infrastructure in stormwater management. Landscape and Urban Planning, v. 187, p. 1-10, 2019. https://doi.org/10.1016/j.landurbplan.2019.03.002

NATARAJAN, P.; DAVIS, A. P. Ecological assessment of a transitioned stormwater infiltration basin. Ecological Engineering, v. 90, p. 261-267, 2016.

OLIVEIRA, D. B. C.; SOARES, W. A.; HOLANDA, M. A. C. R. Análise de desempenho de modelos de infiltração unidimensional de água no solo. Águas Subterrâneas, v. 32, p. 35-42, 2018. https://doi.org/10.14295/ras.v32i1.28947

OLIVEIRA, D. B. C.; SOARES, W. A. Desempenho de modelos de infiltração tridimensional de água no solo. Diálogos: Revista de Estudos Culturais e da Contemporaneidade, v. 3, p. 519-544, 2017. https://dx.doi.org/10.13115/2236-1499v2n18p519

SANTOS, C. A. G.; SILVA, J. F. C. B. C.; SILVA, R. M. Caracterização hidrodinâmica dos solos da bacia experimental do Riacho Guaraíra utilizando o Método Beerkan. Revista Brasileira de Recursos Hídricos, v. 17, n. 4, p. 149-160, 2012.

SILVA JUNIOR, M. A. B.; SILVA, S. R. Impacts of urbanization and climate change in the drainage system of Recife-PE. Revista Brasileira de Geografia Física, v. 9, p. 20342053, 2016.

SOUZA, E. S.; ANTONINO, A. C. D.; ÂNGUlO-JARAMILlO, R.; NETTO, A.M. Caracterização hidrodinâmica de solos: Aplicação do método Beerkan. Revista Brasileira de Engenharia Agrícola e Ambiental, v. 12, p. 128-135, 2008.

VAN GENUCHTEN, M. Th. A closed-form equation for predicting the hydraulic conductivity of unsaturated soils. Soil Science Society of America Journal, v.44, p.892-898, 1980. 